DARIA VASYLCHENKO

Kiev National University of Construction and Architecture, e-mail: vasilchenko.dasha21@gmail.com
Manuscript submitted 2020.03.16 - revised 2020.03.24,

initially accepted for publication 2020.03.26, published in March 2020

\title{
ARCHITECTURAL PERIODS OF THE UKRAINIAN NON-FORMAL EDUCATION
}

\section{OKRESY ARCHITEKTONICZNE UKRAIŃSKIE EDUKACJI POZAFORMALNE}

DOI: 10.30540/sae-2020-004

\begin{abstract}
The article considers three conditional formation periods of the extracurricular education in Ukraine (before the revolution of 1917, the Soviet era, the period of independent Ukraine). The features of extracurricular institutions of each period, the formation purposes, the main tasks of the periods, the implementation forms of extracurricular education are studied. The description of Ukrainian landmark buildings of each period is given. The modern problems such as the problem of moral and physical obsolescence of educational spaces, private establishments control system, the lack of regulatory documents for extracurricular institutions design, difficulties related to functioning of extracurricular education system in the structure of united territorial communities and the fate of abandoned cultural centres are reviewed. Development trends of extracurricular institutions of Ukraine are revealed. The question of the extracurricular educational system formation in foreign countries is touched upon and the specifics of foreign extracurricular educational systems are revealed.
\end{abstract}

Keywords: extracurricular institution, non-formal education, community house, architectural periods, "Settlement", care concept, development concept

\section{Streszczenie}

Artykut dotyczy trzech okresów tworzenia edukacji pozaszkolnej na Ukrainie (przed rewolucja 1917 roku, era Sowiecka, okresem niepodległej Ukrainy). Badane sa cechy instytucji pozaszkolnych każdego okresu, cele formacyjne, główne zadania okresów, formy realizacji edukacji pozaszkolnej. Podano dokonano opisu ukraińskich zabytków każdego okresu. Artykut rozpatruje wspótczesne problemy, takie jak problem moralnej i fizycznej dezaktualizacji przestrzeni edukacyjnych, system kontroli placówek prywatnych, brak dokumentów regulacyjnych dotyczacych projektowania instytucji pozaszkolnych, trudności zwiąane z funkcjonowaniem systemu edukacji pozaszkolnej w strukturze zjednoczonych wspólnot terytorialnych oraz losy opuszczonych centrów kultury. Ujawnia trendy rozwojowe pozaszkolnych instytucji Ukrainy. Porusza kwestię tworzenia pozaszkolnego systemu edukacji w obcych krajach i ujawnia specyfikę zagranicznych programów edukacji pozaszkolnej.

Słowa kluczowe: instytucja pozaszkolna, edukacja pozaformalna, dom kultury, okresy architektoniczne, „Osada”, koncepcja opieki, koncepcja rozwoju

\section{INTRODUCTION}

Cultural and educational activities accompany a person throughout life. We born and live in the cultural environment of a particular country, region, from the beginning to the end of our lives, we are surrounded by a set of cultural values: family values, social environment values, national and human values. Education, in particular the extracurricular section, participates in the human values formation.
One of the main extracurricular education (EE) tasks is to facilitate the maximum personal fulfilment of each child, that is enshrined in the legal acts of Ukraine, another one task is to promote socialization.

This study is based on the works of Badavi A.A., Molokov D.S. and Merilova I.O., Ignatovich O.V. who researched the experience of foreign countries in the field of extracurricular activities; on the researches made by Boyko O.M., Ignatovich O.V., Kravchenko 
I.L., Shirochin S. and Gutsol A.V. who investigated the EE formation particularities.

The study of EE centres in Ukraine at different times will allow to determine the ways of their actualization in the modern architectural environment and educational context. Studying the experience of different countries in the field of education makes it possible to choose the best world examples and to follow the leading tendencies in reforming the national educational system.

The purpose of this article is to analyse the main forms of extracurricular activities that existed on the modern Ukraine territory since the end of the XIX century and to identify the main development challenges of modern EE.

\section{HISTORICAL REVIEW}

The formation of extracurricular education can be conditionally divided into three stages: the prerevolutionary period, the EE formation in the Soviet era (which also includes the 1917-1922 time span), EE development during the independent Ukraine's lifetime. The research is structured according to the aforementioned periods.

\section{Stage I.}

\section{Pre-revolutionary Extracurricular Education (till 1917)}

The term "extracurricular education" was introduced in the second half of the XIX century to identify the cultural and educational activities of public organizations and individuals [1]. Historically, a part of the present-day Ukraine lands was ruled by the Russian Empire, "in the territory of Ukraine at the close of the 1800 s - in the early 1900 s the general population literacy was low due to the government policy pursued by the Russian Empire. General illiteracy hindered the economic and cultural development of the whole country" [2].

According to the research of Ignatovich O.V., the development of education began in the eighteenth century, the main task of that period was the illiteracy elimination across the population, the formation of public cultural consciousness. The first forms of EE were of social and pedagogical nature, and the teachers of evening and Sunday schools taught voluntarily and unpaid [1].

There was a movement of populism in the Russian Empire of 1860-1880-ies, the form of its realization was so called "going to the people" by noblemen and intellectuals. On the territory of Ukraine, the movement of populism had a cultural nature and was aimed at the advancement of learning among peasants and workers, while in the rest of the territory it had more political nature (propaganda of socialist ideas and democratic change of regime) [3].

The main forms of extracurricular education in the pre-revolutionary period were: community readings, public lectures, community houses, libraries, reclasses, community theatres, people's universities, professional courses for adults, etc. The peculiarity of this period is that EE was opposed to school education, the adult population was an usual educational seeker, as well as children and adolescents who had no other access to education [1]. According to Kravchenko I.L. study, the typological units of extracurricular educational establishments such as art, sport and music schools were already established in the world at the close of the $1800 \mathrm{~s}$ - in the early $1900 \mathrm{~s}$, but the formation of compensatory-type establishments (for children from low-income families, homeless people) was only begun. At first, such establishments were recreational, but subsequently the educational function became their integral part [4].

Public libraries and reading rooms were free educational institutions of EE in pre-revolutionary Russia, which were organized at schools (including Sunday ones). In 1885 the Odessa Public Library was founded. After the 1917 revolution, public libraries were transformed into mass libraries. Similar institutions were founded by district councils, city councils, cooperatives, cultural and educational unions, patrons and peasant communities [5, p. 41-42].

Community House - an extracurricular cultural and educational institution in pre-revolutionary Russia, which usually contained: a library, a reading room, a theatre-lecture hall with a stage, a choir, a Sunday school, a tea-room, a book-shop, sometimes museum, "evening classes with literacy, mathematics and literature studies; training groups, separate for men and women" [6, p. 159]. In community houses lectures, systematic classes, exhibitions, readings, interviews, concerts, craft courses were held, later they were started to use for advocacy and propaganda activities, also as reception rooms for specialists and for the activities of societies (the first Russian community houses appeared in the latter half of the 1880 s). Rural community houses were no different from pubs, but only "sophisticated public" visited the community houses in cities. After the revolution, the rural community houses were replaced by readinghouses, peasants' houses, later - by communal farm clubs and state-owned clubs, houses of culture. City 


\section{ARCHITECTURE OF EXTRACURRICULAR ESTABLISHMENTS}

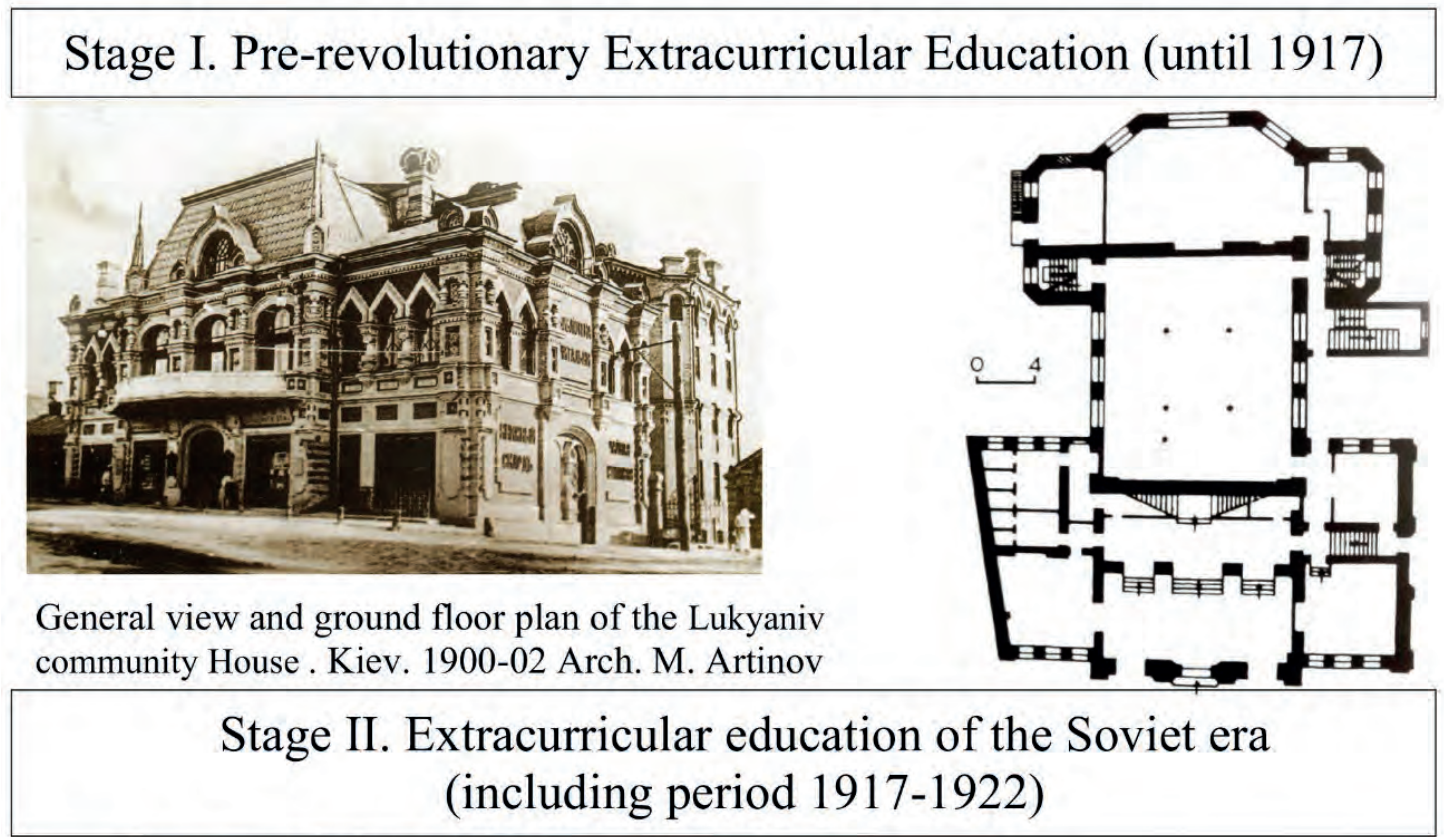

Plan, general view and interior of the Pioneers and Schoolchildren Palace.

Kiev. 1965 Arch. A. Miletsky, E. Bilsky
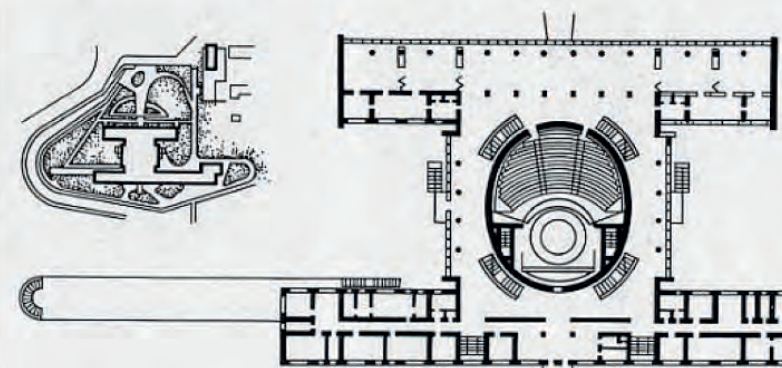

1

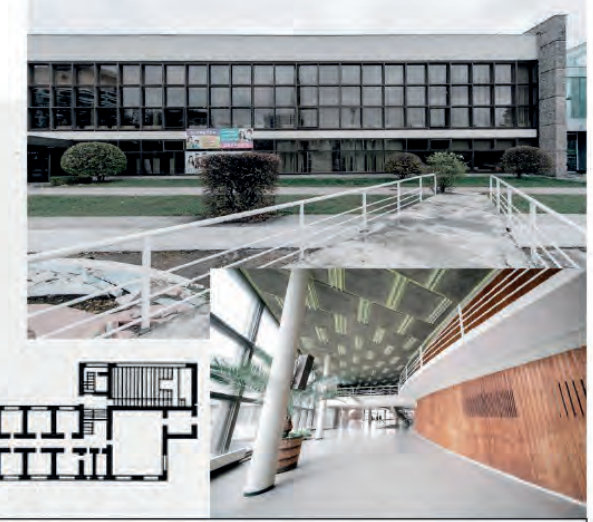

Stage III. Extracurricular institutions of an Independent Ukraine (since 1991)

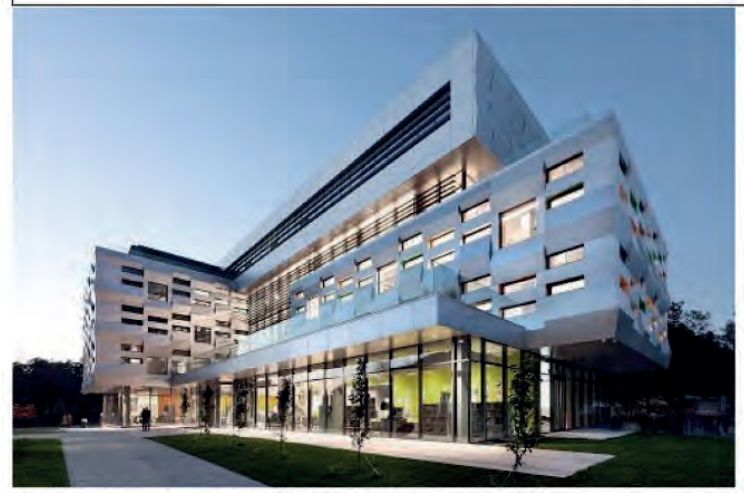

General view and plan diagrams of

Andriy Sheptytsky Center. Lviv. 2017 Arch. S. Benish

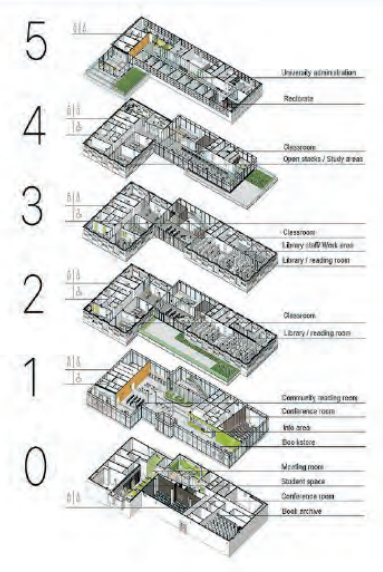

Fig. 1. Architecture of extracurricular establishments

Source: the scheme is developed by Daria Vasylchenko according to [7, 8, 13, 23, 24, 27-29]. 
community houses were transformed into palaces and houses of culture, working clubs. The construction of community houses was financed by the local selfgovernment authorities, patrons, district councils, cooperatives [5, p. 42-44].

Up to the present time, the Lukianiv community House (architect Artynov M.G., construction of 1902-1905 years) and the Trinity community House (architect Antonovsky, construction of 1901-1902) - today the National Opera Academy of Operetta have been preserved and functions as centres of Kyiv cultural life [7].

The Lukyaniv community House (Fig. 1) was founded in 1897 by the Society of Temperance, since 1902 it began to occupy a two-storey building with a basement, designed by Mikhail Grigorovich Artynov in the old Russian style of the XVIII century. The house is made of brick, the roof has a complex structure, the semicircular attic windows are framed by corbel arches, the ventilation pipes are also decorated. The main façade is three-sectioned, the central risalite stands out with wide windows and door slots, previously there was a faceted-in-plan balcony with a parapet and high spires on the horn ends - but, unfortunately, they were lost. The side windows on the first floor are completed with arrow arches, the spaces between them are decorated with three-quarter columns and pilasters. The courtyard facade is distinguished by the conciseness of the solution, the central triangular risalite is accentuated by a window on the ground floor and by a balcony on the first floor. The threedimensional structure of the house is symmetrical, the ground floor contained a lobby, the second - an auditorium, originally designed for 550 people; around these large rooms were all others: a library, classrooms for evening classes, the building also contained tea and dining rooms, a night shelter, outpatient clinic [8].

After the abolition of the autocracy, the building of the community house was handed over to the Ukrainian Workers' Club; in 1919 the club's cultural and educational section established a working theatre on the basis of the club; in the late 1920s early 1930s, the building was donated to the trade union organization of the Lenin Tram Park, thus it was given the name of the Trammer Club; after the WWII the building became Kiev tram and trolleybus management House of Culture [9]. In 1972-1974 architectural replanning of the building and repairs and redevelopment of internal premises were carried out [8]. The modern address of the former Community House is Degtyarivska Street, 5: now it serves as the Kyiv Small Opera House. This example is very interesting because, firstly, it has survived during so many social upheavals, and secondly, it has always served for a cultural function, and thirdly, the old day's architecture is the decoration of the modern city.

One of the significant steps in the formation of children's EE is the "Settlement" movement. The purpose of this organization was the cultural and educational activities for low-income children and adolescents. In 1905 a children's colony was organized, later the "Day shelter for children" appeared in Moscow, which contained a children's club and a kindergarten, workshops. Experimental work and handicraft courses, educational process of children, adolescents, kindergartens and hobby groups for children were conducted, in 1907, a primary school began to work on the basis of club, cultural and educational activities were also conducted among adults [5, p. 839-840]. The activists of the first club in Moscow were teacher Shatsky S.T. and architect Zelenko O.V. (during his trip abroad he became acquainted with the activities of Western children's clubs and had the aim of introducing a similar one to his country), Louise Schleger, Azarevich and others [5, 4].

\section{Stage II. \\ Extracurricular education of the Soviet era}

In the early days of the USSR, extracurricular education was a complex of activities aimed not only at the education of children and adolescents, but also of adults, as the general level of population culture was low. The extracurricular education of the Soviet era had socially pedagogical character and was aimed at educating Soviet identity.

The foundation of the extracurricular education unit of Ukraine dates back to 1918 [10]. The following documents: "Regulations on Uniform Labour Schools" (1918), "Declaration on Uniform Labour Schools" (1918) [1] were among first to adopt, the campaign against illiteracy took place. The Decree of 1919 "On the Elimination of Illiteracy among the Population of the Soviet Union" obliged all residents in ages between 8 and 50 who were unable to read and write, to study their native or Russian language [2]. On the territory of Ukraine from 1923 till 1936 the association named after V. Lenin's “Downright Illiteracy” worked, hobby groups and schools were created, individual work was also carried out; the teaching was conducted simply by educated people, by upperclassmen, students and teachers. The termination of the company in 1936 is 
linked to the statement on the complete elimination of population illiteracy [11].

One of the main achievements of the extracurricular education of the Soviet pre-war period is the network construction of extracurricular institutions (EI) as methodical centres for the development of this education sector, also the organization of a scientific and pedagogical institute of extracurricular methods in 1925 should be mentioned. After the decision of the Central Committee of the CPSU (b) "On measures for the deployment of extracurricular work among children" profile extracurricular establishments were created. In the period from 1934 to 1941, extracurricular networks in almost all regional centres and major cities of Ukraine were developed [10]. The wartime caused great harm to the country's EI and their material and technical facilities.

Formation of extracurricular education in the Soviet post-war era is considered in Gutsol A.V. dissertation [12] (Table 1). The author identifies the study period (1946-1991) into four stages.

Table 1. Extracurricular education development stages in the post-war Soviet times

\begin{tabular}{|c|c|c|c|c|}
\hline Stage & Legal basis & The main tasks & Features of the period & Impact on EEI \\
\hline 1946-1958 & $\begin{array}{l}\text { Law "On the 5-year plan for the } \\
\text { reconstruction and development } \\
\text { of the economy of the USSR for } \\
\text { 1946-1950" }\end{array}$ & $\begin{array}{l}\text { Network development after } \\
\text { WWII }\end{array}$ & $\begin{array}{l}\text { - Applied nature of training; } \\
\text { - focus on physical and health rehabilitation of } \\
\text { children; } \\
\text { - reducing child crime and neglection; } \\
\text { - the need to restore the logistics base }\end{array}$ & $\begin{array}{l}\text { - Network expansion of } \\
\text { pioneering and children's } \\
\text { wellness camps, sports clubs }\end{array}$ \\
\hline 1958-1973 & $\begin{array}{l}\text { Law "On Strengthening the } \\
\text { School's Relationship with Life } \\
\text { and Further Developing of Public } \\
\text { Education" }\end{array}$ & $\begin{array}{l}\text { Polytechnic education to } \\
\text { increase the number of skilled } \\
\text { workers }\end{array}$ & $\begin{array}{l}\text { - Modernization and innovation activities of the } \\
\text { hobby groups; } \\
\text { - strengthening of the profiling process; } \\
\text { - improvement of financing; } \\
\text { - low level of logistical support }\end{array}$ & $\begin{array}{l}\text { - Diversification of El work areas; } \\
\text { - emphasis on the development } \\
\text { of technical direction }\end{array}$ \\
\hline 1973-1984 & $\begin{array}{l}\text { "Statutory framework of the USSR } \\
\text { and the Union Republics for Public } \\
\text { Education" }\end{array}$ & $\begin{array}{l}\text { Regulation of the legal } \\
\text { framework of EE }\end{array}$ & $\begin{array}{l}\text { - Continuation of the introduction of polytechnic } \\
\text { education policy; } \\
\text { - strengthening of extra-curricular technical, } \\
\text { excursion-tourist, naturalistic work }\end{array}$ & $\begin{array}{l}\text { - Legally approved material and } \\
\text { technical base for each type of } \\
\text { software; } \\
\text { - the typical provisions of the El } \\
\text { functioning are accepted }\end{array}$ \\
\hline 1984-1991 & $\begin{array}{l}\text { "Main directions of reform for } \\
\text { secondary and vocational school" }\end{array}$ & $\begin{array}{l}\text { Reforming the EE institution } \\
\text { system based on the national } \\
\text { pedagogy traditions }\end{array}$ & $\begin{array}{l}\text { - Underestimation of national, regional } \\
\text { peculiarities of state development; } \\
\text { - Democratization of social and political life; } \\
\text { - strengthening the centralization of education } \\
\text { management }\end{array}$ & $\begin{array}{l}\text { - Increasing the number of } \\
\text { complex software; } \\
\text { - further branching of the } \\
\text { software network; } \\
\text { - clearly defined material and } \\
\text { technical base }\end{array}$ \\
\hline
\end{tabular}

The author identifies four main tendencies in the formation of the EI system of the Soviet post-war period:

1. Dependence of features of EI development stages on social tasks facing the state and society.

2. Profiling of EE.

3. Professionalization of the EI staff.

4. Improvement of the mechanism of financing of extracurricular institutions.

Extracurricular educational institutions in 19461991 had four sources of funding: state, local, chief and self-financing [12].

The modern researcher of the Soviet building of Kiev Semyon Shirochin notes that the main tendency of the Soviet period was socialization, including leisure. Soviet clubs have borrowed the idea of creating a publicly accessible cultural institution from community houses [7]. At first, institutions were transformed from community houses into clubs and later-into the houses of culture (after the 1917 revolution) and then - into palaces of culture (in 1930s). The author also notes that large enterprises were often the source of financing for houses of culture and clubs (Fig. 2).

According to Ignatovich's research, the prerevolutionary extracurricular education system was transformed in the Soviet era in four directions:

1. The function of adult education, which is gradually adopted by formal education: workers' faculties, schools at industrial plants, schools of working youth, evening schools, etc. were formed.

2. Extracurricular education, which was aimed specifically at the child population and youth, and 


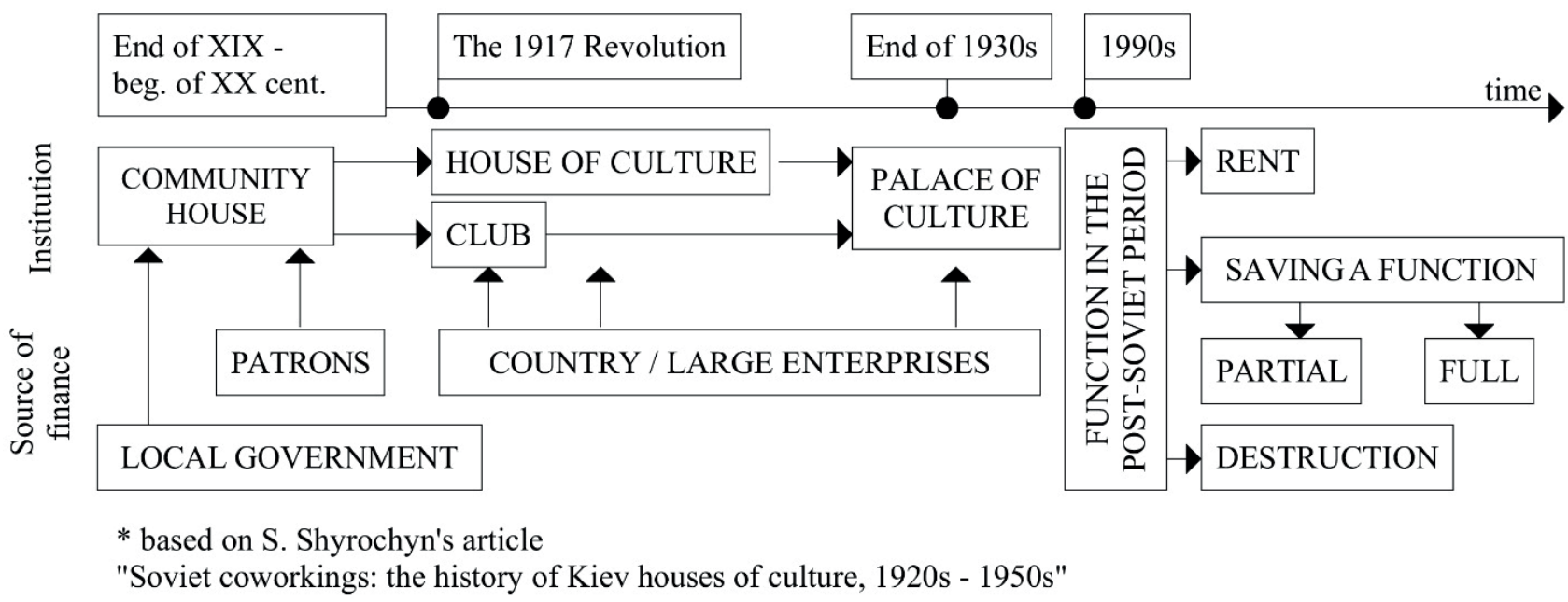

Fig. 2. Key points of S. Shirochin's study [7]

Source: the scheme is developed by Daria Vasylchenko according to [7].

was presented in the following forms: palaces and houses of pioneers and pupils, children and youth libraries, palaces and houses of culture, sport palaces, houses of techniques of vocational school students, young technicians (naturalists, tourists) stations and clubs, children railways, sport schools, pioneer camps, labour and recreation camps, teens' interest clubs, technical and artistic clubs, sport sections; music and art schools.

3. Professional improvement system that was implemented in the form of internships and training courses.

4. The system of evening and extramural education aimed at raising the cultural level of the working population [1].

The design and construction of cultural buildings in the USSR were conducted mainly with the use of typical projects. A landmark building of Soviet times in Kyiv is the modern Kyiv Palace of Children and Youth (Fig. 1), which was built in 1965 according to design of A. Miletsky and E. Bilsky in the style of Soviet modernism and firstly was called the Palace of Pioneers and Schoolchildren. Monumentalists Rybachuk A. and Melnichenko V. worked on the project, and developed mosaics for the interiors and the decorative pool near the building. The composition of the institution is emphasized by the highest flagpole in Kiev - 50 meters high. The three-storey palace has an area of $12,000 \mathrm{~m}^{2}$ and contains halls, offices, laboratories and workshops, as well as an observatory, cinema and concert halls. In its foundation year there were 400 educational groups and 8000 children were engaged, today there are about 600 educational groups in the palace and 10000 children attend them [13].

\section{Stage III. \\ Extracurricular education in independent Ukraine}

Cultural and educational activities in the modern world begin with the family, then other people communities flow into our lives, the interconnections between us and society increase as time goes on. The goal of modern Ukraine, as well as other humanistic countries, is to implement laws to support and develop the education sector, including extracurricular ones (in particular, the law on extracurricular education that enshrines the right of each child to develop his or her abilities according to his or her own desire [14]). In connection with the decentralization reform launched in 2014 [15], the question about the quality and equal accessibility of EE for all children comes up, how to organize it in the best possible way locally in the context of the united territorial communities (UTC) existence.

Children EI should be attractive and interesting to its users. The competent use of architectural and design techniques can help to improve the exterior of the building and its interior spaces, it's necessary to focus on the harmonious combination of the building and the environment, the ergonomics of the context, the evolving nature etc. These techniques are aimed at creating a space that encourages the child to act or to react emotionally, helps him/her to develop [16].

The issue of reforms in the field of EE is relevant today, the reform continues, among the latest achievements we should note the concept of reforming the system of providing the population with cultural services approved in 2019, which contains the decision to develop a system for monitoring and assessing the quality of cultural services, creating conditions for 
the cultural services formation and highly qualified personnel, infrastructure modernization policy implementation, reform of financial system support, approval of minimum standards of citizens providing with cultural services [17].

On December 23, 2019 there was an eventpresentation of the last year achievements of extracurricular education: speakers paid special attention to legislative support of extracurricular education, state-public partnership in the field, improving the quality of extracurricular education, successful projects (expansion of media space), the development of extracurricular activities in communities, teacher training and development of software and methodological support for extracurricular education [18].

On January 13, 2020, a "Guidebook for managers" was published, stating that planning a viable education network should be the most important task that local governments should fulfil [19, p. 250] by analysing the UTC own situation, developing their vision and action plan on that basis. So, now, with the help of partners and enthusiasts, Ukraine is improving its legislative and public support for the field of EE, but there are still enough challenges, as some time is passing between the enactment and its successful implementation.

Studying the experience of foreign countries and introducing the best models into the practice of Ukrainian EE is one of the nowadays tasks.

The experience of Russia: Badawi's research on the experience of modern Russia emphasizes the need to develop standards for the design of all-types extracurricular institutions. In his study, Badawi cites the classification of children educational centres by the spatial model type that is used (small - designed for a residential group or quarter, medium - calculated for a building estate, large - for a district, integrated - as a unit of the complex "school - kindergarten children educational centre"), and also compares them by location, funding source, most commonly used scheduling etc. It is also noted that in modern Russia, the most widespread and most required is the multifunctional children educational centre, which places in close proximity to housing and is often built-in [20]. The author also notes that such centres do not have uniform standards for design.

The experience of Europe: According to Molokov, EU residents refer to non-formal (extracurricular, supplementary) education as to a component of lifelong learning, which should be first of all accessible [21]. The author notes that all existing concepts in the field of non-formal education can be divided into two groups: the care concept and the development concept. In her work, Merilova notes that Ukraine is currently in a state of uncertainty about one of the concepts domination of, in her opinion, the "development concept" is a more economical-costly option for Ukraine, since it requires a significant modernization of the existing institutions, material and technical base, as well as expanding the existing extracurricular network. Alternatively, the "care concept" provides much more state-attention only for problem children, and the rest of the children population should be served by private EI. The problem of the second variant is the complexity of controlling the actions of private EI [22].

There is a problem of moral and physical obsolescence of educational spaces in Ukraine: educational reforms require certain solutions, in particular the architectural environment of educational spaces, but during the independence, very few buildings were designed and constructed specifically for cultural purposes.

The contemporary Ukrainian example of cultural space is the five-storey building of the Metropolitan Andrey Sheptytsky Centre in Lviv (Fig. 1), built on the territory of the Ukrainian Catholic University specifically for the library. The area of the Centre is $6027 \mathrm{~m}^{2}$. The main premises are a library, an exhibition hall, coworkings, training rooms, a conference room, administrative rooms, a coffee shop, a children room and a souvenir shop. The project was designed by the German company Behnisch Architekten and AVR Development, and the main architect of the project was Stefan Benisch. The library is a training and cultural centre. The environment was designed with a view to create a barrier-free environment, that also should be accessibly for visually impaired people. The peculiarities of the building are equipped terraces and green roofs $[23,24]$. This library is an example of modern solution of the cultural, educational space that is accessible not only for students of the institution, but also for everyone interested (for a small fee) [23].

Due to the decentralization reform (which includes, in particular, the hub school establishment and their branches and the organization of students' transportation from areas where it is not economically justified to maintain their own institution or branch), some educational buildings remain abandoned and require either renovation, rehabilitation or total 
elimination. UTC are now free to decide the fate of such institutions at their discretion. It is necessary to highlight the idea of creating coworking as one of the possible ways to use the old building of a Community House or club among contemporary decisions about the public cultural space renovation. This decision was initiated by the residents of the village of Krasiv (Lviv region), developed by A. Space and approved by UTC. In the reconstructed space it is planned to hold hobby group classes, to arrange a library centre, places for convenient communication and work. It is planned that further renting of coworking in the picturesque village should generate some income for UTC [25]. This example is a good variant of renovating an outdated space, but many cultural and educational facilities are still waiting for some solution and are just empty. The architects task will be to create spaces guided by the deep interdisciplinary knowledge and to persuade the population to implement such solutions [26]. The study of world analogues of the abandoned cultural centres use is an under-researched topic and has to be refined.

\section{CONCLUSIONS}

The pre-revolutionary stage of the extracurricular education formation was aimed at cultural and educational activities among the underprivileged: the "Settlement" movement, whose main audience was children and adolescents, should be noted; as well as the activities of Community Houses, reading rooms, public libraries, etc. aimed at eliminating illiteracy mainly among adults and adolescents and forming the cultural consciousness of the population.

The main achievement of extracurricular education during the existence of the Soviet system was the formation of an extensive network of institutions almost all over the country. In today's Ukraine, the achievements are a significant branching of the extracurricular education system, the existence of not only public but also private institutions. However, there remain unresolved issues regarding the control of private establishments, design rules for different spatial models institutions, and the existence of extracurricular education system in the structure of UTCs and the fate of abandoned cultural centres.

\section{REFERENCES}

[1] Ignatovich E.V.: From 'out-of-school education' to 'supplementary education' in Russia: a comparative historicallinguistic analysis of the concepts (the 18th - 21st centuries). Continuous education: XXI century. №3 (23), 2018, 2-26. Retrieved [04/02/2020] from - https://cyberleninka.ru/article/n/ot-vneshkolnogo-obrazovaniya-k-dopolnitelnomusravnitelnyy-istoriko-lingvisticheskiy-analiz-kontseptov.

[2] Boyko O.M.: Organizational stage of illiteracy elimination (1919-1922 years of the XX century). Psychological and pedagogical problems of rural school, 45, 2013, pp. 202-208.

[3] Baran S.A., Barabash T.M., Kokotko N.V., Polishchuk T.S., Tarnavsky R.B.: An online history guide for distance learning. History section. Lviv, 2010, 101. Retrieved [01/02/2020] from - http://oman.lviv.ua/pages/library/history_I_ oz.pdf.

[4] Kravchenko I.L.: Development of the architecture of the informal education institution in the period between the end of the 19th and the beginning of the 20th century. SPACE \& FORM: Scientific Journal of the Polish Academy of Sciences and West Pomeranian University of Technology. Szczecin, 2019, No. 37, pp. 197-206, ISSN 2391-7725, ISSN 1895-3247 (Index Copernicus Value), DOI: 10.21005 / pif.2019.37.E-01.

[5] Pedagogical Encyclopedia / Chief. ed. Kairov I.A. and Petrov F.N., vol. 3, Moscow, Soviet Encyclopedia, 1966,880 p. with illus.

[6] Bim-Bad B.M.: Pedagogical Encyclopedic Dictionary. Moscow. The Great Russian Encyclopedia, $2008,528$.

[7] Shirochin S.: Soviet coworkings: The History of Kiev houses of culture of the 1920s - 1950s. Skyscraper: Environment. 2018. Retrieved [01/02/2020] - https://hmarochos.kiev.ua/2018/01/24/sovetskie-kovorkingi-istoriya-kievskihdomov-kulturyi-1920-h-1950-h/.

[8] Summary of Historical and Cultural Monuments of Ukraine: Kiev: encyclopedic edition. Book. 1, Part 1. A-L / editorial board: executive editor Tronko P. and others: Compiled by: Gorbik V., Kiporenko M., Fedorova L. Kiev, 1999, 608, with illus, ISBN 966-95478-1-4.

[9] Kiev. Encyclopedic Reference Book. Chief Editor Kudritsky A.V. Kiev, 1985, pp. 363-364.

[10] Historical stages of formation and development of the extracurricular education system. Kharkiv National Highway University Training Site Retrieved [06/02/2020] from - http://dl.khadi.kharkov.ua/mod/book/view. php?id=35319\&chapterid=5387.

[11] Tkachova L.I.: Association "Downright Illiteracy" named after V. Lenin. Encyclopedia of Contemporary Ukraine: Society. 2006. Retrieved [05/02/2020] from - http://esu.com.ua/search_articles.php?id=29405. 
[12] Gutsol A.V.: Development of the system of extracurricular educational institutions in Lugansk and Donetsk regions (1946-1991): Cand. of ped. sciences diss. abstract.: Special. 13.00.01 "General Pedagogy and History of Pedagogy". Lugansk national university named after Taras Shevchenko. Lugansk, 2010, 20 p.

[13] Beba Y.: Where you work: I work at the Kyiv Palace of Children and Youth. The Village Kiev, 2017. Retrieved [26/02/2020] from - https://www.the-village.com.ua/village/business/wherework/265333-ya-pratsyuyu-vkiyivskomu-palatsi-ditey-ta-yunatstva.

[14] On Extracurricular Education: Law of Ukraine No. 1841-III of 16 January. 2020 Database "Legislation of Ukraine". Verkhovna Rada of Ukraine. Retrieved [30/01/2020] from - https://zakon.rada.gov.ua/laws/show/1841-14.

[15] The concept of reforming local self-government and governmental territorial organization in Ukraine: approved. By order of the Cabinet of Ministers of Ukraine dated April 01, 2014 №333-p. Database "Legislation of Ukraine". Verkhovna Rada of Ukraine. Retrieved [30/01/2020] from - https://zakon.rada.gov.ua/laws/show/333-2014$\% \mathrm{D} 1 \% 80$.

[16] Kravchenko I.L., Vasylchenko D.K.: Image in the architecture of children's out-of-school establishments. Modern problems of architecture and urban planning: scientific and technical anthology №49, Kiev National University of Construction and Architecture, Kyiv, 2017, pp. 165-169.

[17] The concept of reforming the system of providing the population with cultural services: approved. By order of the Cabinet of Ministers of Ukraine dated January 23, 2019, No. 27. Database "Legislation of Ukraine". Verkhovna Rada of Ukraine. Retrieved [30/01/2020] from - https://zakon.rada.gov.ua/laws/show/27-2019-\%D1\%80.

[18] Extracurricular education - 2019: ten wins. Presentation of achievements. Ukrinform. Multimedia platform of foreign language of Ukraine. Retrieved [30/01/2020] from - https://www.ukrinform.ua/rubric-presshall/2842251pozaskilna-osvita2019-desat-peremog-prezentacia-dosagnen.html.

[19] U-LEAD with Europe Program Guide Guide. Successful community: providing quality services to citizens and promoting sustainable development. Retrieved [30/01/2020] from - https://decentralization.gov.ua/uploads/library/ file/527/RFL-UA-Web.pdf.

[20] Badavi A.A.: Architectural typology of children leisure and educational centres. Electronic scientific journal. Engineering Herald of Don, №4 (47), 2017. Retrieved [31/01/2020] from - https://cyberleninka.ru/article/n/ arhitekturnaya-tipologiya-detskih-dosugovo-obrazovatelnyh-tsentrov.

[21] Molokov D.S.: Foreign Experience on Service in the Sphere of Children's Further Education. Yaroslavl Pedagogical Bulletin. Psychological and Pedagogical Sciences, №1, 2013, pp. 225-231.

[22] Merilova I.A.: Variant variants of extracuricular educational network's development in Ukraine on the base of world concepts' analysing. Bulletin of the Pridneprovsk State Academy of Civil Engineering and Architecture, № 2 (203), 2015, pp. 52-63. Retrieved [04/02/2020] from - https://cyberleninka.ru/article/n/varianty-razvitiya-setivneshkolnogo-obrazovaniya-v-ukraine-na-osnove-analiza-mirovyh-kontseptsiy.

[23] Perehrest O.: Library with dignity. The Sheptytsky Center was officially opened in Lviv // ZAXID.NET, 2017 Retrieved [26/02/2020] from - https://zaxid.net/biblioteka_z_gidnistyu_n1435960.

[24] Eismunt V.: Sheptytskyi Center was nominated for EU Architectural Prize. Your City, 2018. Retrieved [26/02/2020] from - http://tvoemisto.tv/news/tsent_sheptytskogo_nominuvaly_na_arhitekturnu_premiyu_yes_97378.html.

[25] Troschuk S.: From Rural People's House to Coworking: Where They Seek Money and How They Persuaded Officials. Channel 24. 2019. Retrieved [01/02/2020] from - https://24tv.ua/ru/iz_selskogo_narodnogo_doma_v_kovorking gde_ishhut_dengi_i_kak_ubezhdali_chinovnikov_n1221919.

[26] Kamionka L.: Creative and coordination attributes in architectural education nad in the way of profession for the future. Nacionalnowo Uniwesitetu Lwiwska Politechnika Seria: Architektura. ISSN 2523-4757, Nr 895.2018. Lwów.

[27] Image.URL: https://upload.wikimedia.org/wikipedia/commons/8/8b/Kiev-Lukianovskiy-public-house.png.

[28] Images.URL: http://www.avr-development.com/portfolio/sheptytsky/.

[29] Image.URL: https://photos.wikimapia.org/p/00/01/47/02/90_big.jpg.

\section{Acknowledgments:}

The work was financed by Kiev National University of Construction and Architecture, Architectural faculty Department of the Architectural Theory 31, Povitroflotskyy prosp., 03680, Kyiv, Ukraine

\section{Podziękowania:}

Praca byta finansowana przez Kijowski Narodowy Uniwersytet Budownictwa $i$ Architektury, Wydziat Architektury Katedra Teorii Architektury 31, Povitroflotskyy prosp., 03680, Kijów, Ukraina 